\title{
Park (Uyana): Conceptualization
}

\author{
K. Jayantha ${ }^{1 *}$, RG.Ariyawansa ${ }^{2}$, U. Anura Kumara ${ }^{3}$
}

\author{
${ }^{1} \mathrm{PhD}$ candidate, University of Sri Jayewardenepura, Sri Lanka; Senior Lecturer, University of Kelaniya, Sri Lanka \\ ${ }^{2}$ Department of Estate Management and Valuation, University of Sri Jayewardenepura, Sri Lanka \\ ${ }^{3}$ Department of Business Economics, University of Sri Jayewardenepura, Sri Lanka
}

DOI: $10.36347 /$ sjahss.2021.v09i05.002

| Received: 23.03.2020 | Accepted: 01.05.2021 | Published: 10.05.2021

*Corresponding author: K. Jayantha

\section{Abstract}

Historical evidence proves that 'parks' have been used as a reconciliation tool between humans and the environment since prehistoric times. With the emergence of various forms of gardening, the basic meaning of park took different forms. This led to complications of understanding what it means by a park. Thus, this paper aims to realize the exact definition of Uyana, which is the Sinhala language term for park how the park is used as a term. The authors used Hela Nirukthi Shasthraya or Hela Niyyukthastra as the method to understand the basic definition of park. We used the equation $\mathrm{A}=100 / \mathrm{A}_{\mathrm{n}}, \mathrm{B}=\mathrm{A} / \mathrm{B}_{\mathrm{n}}, \mathrm{C}=\mathrm{B} / \mathrm{C}_{\mathrm{n}}, \mathrm{D}=\mathrm{C} / \mathrm{D}_{\mathrm{n}}$ where $\mathrm{A}=$ Base word, $\mathrm{B}=$ Level 2, $\mathrm{C}=$ Level 3, D = Level 4 and $\mathrm{n}=$ number of pure synonyms, to measure definition power of park. We further investigated how many terms are used synonymously with park, and which were gradually distancing away from the basic meaning of park. Further investigations revealed that the identified meanings given to park were indicating a weak power in terms of the power of those definitions. In addition, the term taxonomy of the term park illustrates that the meaning of the park has differentiated with the global development from its original/ basic meaning.

Keywords: uyana, definitions, nirukthi, recreation, park.

Copyright (C) 2021 The Author(s): This is an open-access article distributed under the terms of the Creative Commons Attribution 4.0 International License (CC BY-NC 4.0) which permits unrestricted use, distribution, and reproduction in any medium for non-commercial use provided the original author and source are credited.

\section{INTRODUCTION}

There is historical evidence that the concept of park (the direct translation to park is uyana in Sinhala. But we argue that the basic meaning of uyana is different from the recent definitions given to garden/ park) was not a recent addition to the term, but it has been around since prehistoric times. For example, the archaeological site Ranmazoo Uyana in Sri Lanka can be pointed out. There is a deep root of legendary history among Sri Lankans regarding the creator of this park. People believe that Rishi Wishrawan (5000 BC) created Ranmazoo Park. They define Ranmazoo Park as "priceless land" (Amarasinghe, 2020; AmazingLanka.com, 2020). There is another opinion that the king Devaanam Piyathissa (3rd century BC) built this uayna (Wisdom Library, 2018). Even in international arena, there are legends as such in relation to the Hanging Gardens of Babylon. Legends say that this garden was built by the Assyrian King Sennacherib in 704-681 BC (Dalley, 1993, 2013): 9th century BC (Krystek, 2010): 1500 BC (Dalley, 1993) in his capital city of Nineveh on the River Tigris, near the modern city of Mosul. There is literature evidence like such in Sri Lanka to prove that this Mahameuna Uyana also belongs to the pre-historic era. Lankadeepa (present Sri
Lanka), which was called as such during the era of Gautham Buddha in 5-6 BC (Cousins, 1996; Ruegg, 1999; Witzel, 2019), was also called as Oojadeepa, Waradeepa and Mandadeepa in the eras of Kakusandha, Konagamana, and Kassapa Buddha respectively (Vidyalankaara Campus, 2001). Also, this Mahameuna Uyana was called as Mahamevna during 5-6 BC. During the eras of Kakusandha, Konagamana, and Kassapa Buddha (Fleet, 1906; Indira Gandhi National Center for the Arts, 2020) Mahameuna Uyana was called as Mahatittha, Mahanoma, Mahasagara. Accordingly, Sri Lanka's Mahamevna Uyana can be described as one of the oldest uyana (parks according to others) in the world with literature evidence. Literature has also shown that there was another duality called Nandana Forest and Jothiya Uyana to the north of the Mahamevna Uyana in the Kingdom of Anuradhapura (Liyanagamage \& Gunawadana, 1987). In addition, according to legendary evidence, the Sigiriya Magul Uyana (Sigiriya royal garden), other aquatic uyana (gardens) and stone uyana (gardens) in Sri Lanka were built some 5,000 years ago by king Ravana (Hela Yugaya, 2012).

Similarly, the concept of park is used in many ways. We used nine online dictionaries to prove that 
fact. 20 (Thesaurus.com, 2013), 39 (Your Dictionary, 2020b), 08 (Synonym.com, 2020), 25 (MerriamWebster Thesaurus, 2020), 1319 (Power Thesaurus, 2020), 418 (WordHippo Thesaurus, 2020), 28 (Synonyms.com, 2020), 37 (Lexico.com, 2020) and 77 (Macmillan Thesaurus, 2020) synonyms given to the 'park' in each dictionary were taken into consideration by us after removing repetitions. We must mention that considering the total sum of the synonyms given by each dictionary without omitting repetitions would become an error. According to the sample of this study (nine online dictionaries) there were 1319 synonyms in use for the term 'park' without omitting repetitions. What this implies is that the term 'park' is used with a weak definition than having a specific meaning. In other words, 'park' is defined with number of outward or out-of-the box definition, rather than with a definite definition. In general it is clear that this term (park) is used in a wide range of meanings such as Abide, Accommodate, Agriculture, Amusement, Arms, Bank, Collect, Common, Corral, Course, Cover, Death, Demise, Deposit, Dwell, Establish, Estate, Exist, Field, Green, Hide, Hug, In Course, Inhabit, Kiss, Land, Live, Locate, Lodge, Pack, Pen, Pitch, Place, Plain, Plantation, Position, Post, Preserve, Range, Relax, Reservation, Retreat, Save, Set, Sojourn, Spot, Square, Stable, Stackable, Timberland, Turf, Vegetable, Woodland (Power Thesaurus, 2020). These different meanings to the park hinder the original meaning of the park. Thus, the definition of 'park' tends to be defined in terms of different requirements. Therefore, to understand the correct meaning of park, it is requiring to use the cause and effect method (Jayantha, RG, et al., 2020; Jayantha et al., 2021).

Vice versa, it is clear that there are diverse range of terms used as a synonym to park such as gardens, Public Parks (National Recreation and Park Association, 2020), Urban Parks (Türkseven Doğrusoy \& Zengel, 2017), Recreational Park (Mansor et al., 2019), National Park (National Parks and Wildlife Service, 2015), Theme Park (School of Hotel and Tourism Management, 2020), Urban Green Space (Nielsen \& Bronwen Player, 2009), Public Lands, Community Garden, Public Lands and Greenways (Gies, 2006), Neighborhood Park (Bai et al., 2013; Epstein et al., 2006; Kaczynski et al., 2014), Mini Parks, Neighborhood Parks, Community Parks, Special Use Parks/Facilities, Open Lands (Addison Park District, 2017) and Cultural Park (Alonso González Peterhouse, 2011). Also, the term park is used in the following terms as well: Industrial Park (Vidová, 2010), Car Park (Idris et al., 2009), Animal Park (Cesário et al., 2020; Khomsi \& Lapointe, 2010) and Eco-Industrial Park (Martin et al., 1996). But there is a difference. The common outcome we expect from a park does not occur in these places. It appears that the term park was used in those places in a different sense. This further confirms that there is no definite definition. Otherwise, its definition is vague and complicated. Also, it is evident that the term park is used as a personal name in many western and eastern countries (Chris, 2021; Joung \& Park-Poaps, 2013; Kim \& Kyu Park, 2007). Examples: Linkin Park (Linkin Park is an American rock band from Agoura Hills), Sandara Park (South Korean singer, actress and television presenter.), Brad Park (Canadian retired professional ice hockey player), Linda Park (Korean-American actress), and Jay Park who is a Korean American rapper, singer, songwriter, record producer, dancer, choreographer, entrepreneur, actor (Chris, 2021).

So, what exactly does the term 'Park' mean? There is a problem. What exactly is the meaning of park? Why did the park originate? What exactly is the definition of park? Going further raises the puzzle. It also adds complexity. Therefore, the main purpose of this study is to investigate the root definition of the term 'park'. Also, there are many definitions of park. Thus, it is difficult to find the exact definition of 'park and provided definitions are questionable.

It is required to measure the power of those definitions of park. That, too, is among the secondary objectives of this study. This makes it easier to understand which definition is suitable to use as a definition for the term 'park'. It also raises the question of the extent to which the terms used as a substitute for 'park' correspond to its basic meaning. If, for some reason, the term 'park' is derived (according to the law of cause and effect), the issue of the extent to which it is reasonable to use two or more different species in the same sense is a problem. There is a need to investigate to how extent can it be justified the use of the synonyms for park. This is also another specific objective of this paper, as well as to explore the reasons for the use of multiple terms for the term 'park' in the real world while examining what they mean by 'park'.

\section{MATERIAL AND METHODS}

Given the nature of this study, it takes the form of a library study when gathering information. Similarly, this study is limited to information on the Internet, due to the global epidemic of the COVID-19. The virus has spread to 199 countries around the world. The death toll now exceeds $3,186,538$ by $2^{\text {nd }}$ May, 2021 (World Health Organization, 2021). However, since knowledge production is an obligation that should not be left for tomorrow, it is the best method to study based on available resources.

\section{Method of understanding the true defining meaning of 'park.' \\ Researchers acted on the data collected so far.}

To consider the basic definition of 'park' the hela nirukthi method, which was used since centuries was used. When using this method, it is required associate the original nature of the word that is to be defined. Therefore, mother tongue word for 'park', which is 
K. Jayantha et al., Sch J Arts Humanit Soc Sci, May, 2021; 9(5): 144-157

uyana was used define what a park is. As the knowledge on English was a limitation, the researchers used uayana, which is a hela (roots of Sinhala language) word in defining park. There is a source of wisdom called sakaaya nirukthi in the hela nirukthi method. To understand the meaning of uyana this sakaaya nirukthi was used. Sakaaya nirukthi has the capability of deriving the original meaning of a word. The word sakaaya was made of swa + kaaya (own+body). Because this method allows to look into the own body of a word it hinders a person to provide synonyms or descriptions to a word as a method of providing a definition. Because of this advantage of sakaaya nitrukthi the researchers decided to use this method.

\section{Method of investigating to what extent the other terms used in parallel to the 'park' match the definitions of the 'park.'}

To obtain an idea about the synonyms for 'park', online dictionaries were used based on the convenience sampling method. Through Google search engine, 'park' as a key word was searched. First 09 results provided through online dictionaries were used to further carry on the study. A word can be considered in several ways. That is, if the keyword is treated like the first level, then the terms used in the second string are the second level terms/ synonyms. The terms received for a second level synonym are third level strings/ synonyms. Strings obtained for a third level words are considered as fourth level synonyms. Strings obtained for a fourth level words are fifth level synonyms. If the original word/ base word (level) is A, level $2=\mathrm{B}$, level $3=\mathrm{C}$, level $4=\mathrm{D}$ and level $5=\mathrm{E}$. Since the meaning of terms through A and $\mathrm{E}$ gradually become contradictory and minimised value, it was determined should there be an ability to define uyana with at least B level definitions. Therefore, the researchers chose commonly used 17 synonyms.

\section{Method of measuring the power of definitions.}

To measure the power of definitions, 14 words definitions of park selected through 09 dictionaries and different organisations. The basic idea of those definitions, the level of definition and its power were calculated using the following formula introduced by us previously (Jayantha, Ariyawansa, et al., 2020b).

$\mathrm{A}=100 / \mathrm{A}_{\mathrm{n}}$

$\mathrm{B}=\mathrm{A} / \mathrm{B}_{\mathrm{n}}$

$\mathrm{C}=\mathrm{B} / \mathrm{C}_{\mathrm{n}}$

$\mathrm{D}=\mathrm{C} / \mathrm{D}_{\mathrm{n}}$ where $\mathrm{A}=$ Base word, $\mathrm{B}=$ Level $2, \mathrm{C}=$ Level

$3, \mathrm{D}=$ Level 4 and $\mathrm{n}=$ number of pure synonyms.

\section{Method of categorising the concept of park / Uyana}

Data were collected from internet where the term 'park' is used in different places. In the highest sense (according to hela nirukthi method) 'U' of uyana was considered as loukika and lookoththara. In the highest sense of loukika 'U' was identified as "it" or "they".

\section{Analysis of Data \\ Understanding the true defining meaning of 'park'}

The concept of 'Uyana' can be analyzed according to hela Nirukthi method. The genre of hela nirukthi method can be traced back to 2600 years ago according to literary sources. Hela Nirukthi wisdom is considered essential for the etymology to be understood of the Tripitaka scripture (there are 57 scripture, which is often regarded as one of the sources of all Sri Lankan historical texts) in terms of theories or sutta (T.W. Rhys Davids \& C.A.F. Rhys Davids, 1900). There are various sutta in the scriptures that describe how to practice hela nirukthi wisdom such as Nirukthi Patha Sutta (Buddha Jayanthi Thripitakaya, n.d.; Jayantha et al., 2021; Jayantha, Ariyawansa, et al., 2020a). This Nirukthi Patha Sutta is essential to obtain examples when practicing hela nirukthi method. For example, the meaning of the term Raja (king in English) is who heals (ra) the people (ja). Accordingly, the term 'Raja' is derived from the combination of letters ra and ja. Thus, when interpreting the meaning of a verse, it is obvious that there is no doubt in it that there is a cause and effect. The meaning of the verse is the reason behind the birth of the word raja. In short, to understand the doctrines shown in these books is necessary to understand nirukthi wisdom.

It is evident that the word "Uyana" (U+Yana) is made up of two Sinhala words. The letter 'U' means the Lord. Here the Lord can be distinguished in many ways. However, in Sri Lankan culture, the tradition that existed 2600 years ago can be identified in two main categories. It means the lord of the current world and the lord of the ideal world (secular class). In both worlds the kings are the leaders. There are kings in both the secular class and the king of the world class. This is a unique feature nowhere else in the world. Before the commencement of the Sri Lankan royal family, for example Sri Lankan legends testify that there were 158 kings before the dynasty started in the 5th century BC. These kings represented dynasties such as Maha Sammatha Manu dynasty (Aung-Thwin, 2005; Charney, 2006; Lieberman, 1986), Pulasthi dynasty, Bali dynasty, Tharu dynasty, Wishwan Muni dynasty, Raawana dynasty, Wibheeshana dynasty (seven kings), Devana Raavana dynasty (14 kings), Palamu Dadimunda dynasty (five kings), Weeramunda dynasty (14 kings, Murunda dynasty (14 kings), Desha dynasty (two kings),Wardhana dynasty (10 kings), Shaka dynasty (15 kings), Sekara dynasty (nine kings), Thilaka dynasty (seven kings), Murandu dynasty (10 kings), Naaga dynasty (12 kings), Singha Raaja dynasty (10 kings), Soorya Raaja dynasty (eight kings), Warna Raaja dynasty (12 kings) and Bamba (three kings) (Aung-Thwin, 2005; Charney, 2006; Lieberman, 1986). Thereafter, there is an orthodox dynasty (Strathern, 2009) that dates from the 5th century BC from King 
Vijaya. That dynasty ruled the island until the British completely conquer Sri Lanka in 1818 (Herath, 2018b, 2018a; Sivasundaram, 2007). In this respect, the island had been ruling for generations from 5000 to 10,000 years with a documentary and written historical record. These dynasties are to be regarded as worldly lords including the British Queen (governors and other officials served as representatives of the queen until Sri Lanka gained independence in 1948), Prime Ministers after 1948 and the Presidents after 1978 in Sri Lanka.

In addition, there is another group of dignitaries/ uththama in the land of Ceylon. They are also descendants of the royal family. But this dynasty has only one king. It was the Buddha. The Sangharaja symbolized this sovereignty, which lasted until the British colonial occupation of the island of Ceylon by the British in 1818 (Houtart, 1976). There are two more Buddhas in this generation. It is called pratyekabuddha or paccekabuddha Buddha and Shrawaka Buddha (Acharya, 2002). They are also considered to be noble. In addition, there are four groups of Bhikkhu, Bhikkuni, Upasaka and Upasika. In that sense, most of the Buddhists can enter this noble caste. When Sri Lanka became a target of foreign invasions, in addition to the Hela Buddhist religious elite / noblemen a number of Hindu, Christian and Muslim clergy were arising in the country and they are also accustomed to being treated as Uththama. However, as they are not aiming to attain nibbana, there is a doubt of considering them as uththama. In addition, the evolution of the political system from the feudal period to the modern capitalist system has opened a new class of non-traditional elites. They are the upper- and middle-class people who have money. During the colonial rule, the elite of the money originated with the liquor trade and so on. At present, a new class of wealthy people has emerged from legal and illegal practices such as contract work, liquor licenses, gem mining, road licenses, drug, and arms trading. All these may be seen as the supreme (elite) class of the present society, but it is doubtful to what extent the pre-eminent virtues existed in the present. But it is worth considering as a product of the current political economy. That fact cannot be ignored because it is a living reality today.

It is in this sense that the concept of uyana has emerged considering the term uthuman (noble in English). There are two types of uyana for the two types of uththama. It means the uyana of the Lord of the secular world and the uyana of the Lord of the current worlds/ worldly world. Ceylon history provides examples of two types of uyana that are relatively special. One is the Ranmazoo Uyana. Legend and written history of this uyana testifies that it was used by the lordship/ uththama of current world. Legend has it that the Rishis who ruled the country used the garden. Thereafter, written history testifies to the use of this garden by the kings and their lords. Although historians have interpreted the name Ranmasu Uyana as "the place where goldfish lived". Yet researchers of this study interpret it as a place was used by people who concerned of masuran or money. "fish-based" because it was used by fishermen. The reason for giving this definition is because of the raja example provided under nirukthi method of Thripitaka. Therefore, it is evident that the Ranmasu Uyana is a place consumed by the people of worldly world. In addition, there can be uyana seen in this island (Helabima) for the Most Glorious of secular world. For example, Mahamevuna Uyana can be introduced. This uyana is regarded as a park dedicated to the Buddha's great sages. Nevertheless, this uyana is a devoted territory of four kinds Bhikkhu, Bhikkuni, Upasaka and Upasika. This implies that Mahamevuna is a uyana dedicated to the Lord Buddha or the people of secular world. However, researchers interpret 'Mahamevnawa' (maha + mawuna) as a 'garden created for the Lord Buddha'. In the Hela tradition, what is often referred to as the Maha is used to clarify something that the Buddhist monks claim. The Maha Bodhi which is also known today as the Jaya Siri Maha Bodhi, Maha Seya is also known as the Ratnamali Maha Seya at present are places that relate to the Buddha. Similarly, according to the uncontested legendary history of Maha Nuwara (Kandy) also are connected to Buddhists.

However, in the present world sense, the meaning what appears to be of $U$ in uyana slightly different. The term 'u' appears to be "it" / "they" in English meaning. This implies that, it is possible to substitute a person/ thing of any category as "it/ they". For example, a children's park (uyana) is where children go. In this context, young children considered as "they" or " $\mathrm{u} / \mathrm{un}$ ". The place where lovers go is considered a lover's park (uyana). Here the lovers are un. A park located in a city is Nagara Uyana/ urban park. The term 'urban' is also "it/ u". In this way, this secondary division seems to have been created to suit the prevailing socioeconomic background. However, what has happened is that the substitution of substitutes, which is "it" did not necessarily change but the nature of "it" was replaced with a name. On this basis, in the future, there will be a park that they (they here are elders) go as an elderly park. There will be a park that they (they here are adults) go as an adults' park. There will be a park that they (they here are villagers) go as villagers' park. There will be a park that they (they here are entrepreneurs) go as an entrepreneurs' park. What is clear through this analysis is that $\mathrm{U}$ of uyana ( $\mathrm{u}+\mathrm{yana}$ ) was used to define noble or uthuman. Later it was used to define any category of population and the yana was defined as "go". Thus, uyana or park is a place where nobles go.

The use of word uyana/ park for place where ratha (cars) halt as a car park is problematic. The real word should be ratha gala/ car halt. Because cars are inanimate things that cannot be gone by itself. Similarly, the use of terms such as Rose Park, Na 
flower garden and Flower Park is problematic. It would seem justifiable to treat them as forests such as Rose Woods/ Rose Forest.

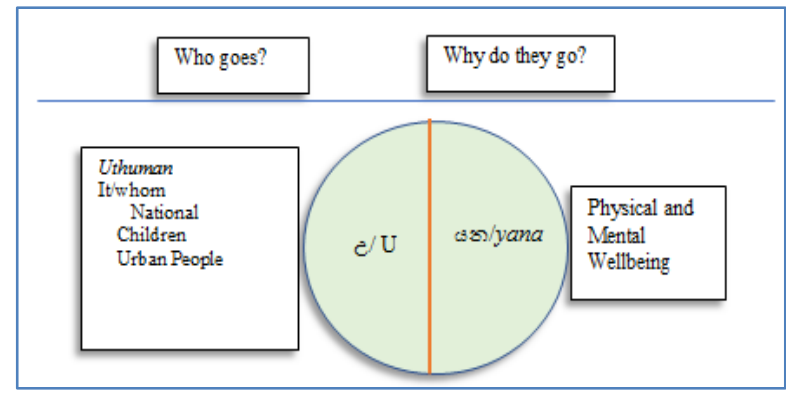

Fig-1: Concept of 'uyana'

Figure 1 depicts the whole of what is defined by the concept of 'uyana' as a purpose that anyone can go. In other words, a place without purpose is not a park. A person goes to a park with a purpose. It is very clear that two aspects must be addressed for the definition to be fulfilled. That is 1 . Who goes and 2 . Why does go? U or Uthuman/ 'they' are the people who go. By the time any population category became the people who go. Why do they go (yana)? Because uthuman need mental and physical wellbeing. That is why the original meaning, which is " $u$ " has not changed though the pronouns were substitutes " $u$ ". Therefore, that there is no difference in meaning occur no matter how many words such as national, child, urban and other terms are used instead of $u$. That is why the original meaning is untimely/ akaalika. Thus, the definition is consistent in all three periods: past, present and future. Also, the term 'why' gives another hidden meaning. You must be very specific about where you are going. It must be explained by understanding the ancient uthuman's purpose. One of the reasons for that was both worldly and secular uthuman had the same purpose. That was physical and mental wellbeing. Therefore, it is not difficult to find an answer to why does go. To summarize, it can be clarified that a specific population goes to a place to obtain physical and mental wellbeing becomes uyana/ park.

Investigating to what extent the other terms used in parallel to the 'park' match the definitions of the 'park':

As described in the method, if the original word/ base word (level) is A, level $2=\mathrm{B}$, level $3=\mathrm{C}$, level $4=\mathrm{D}$ and level $5=\mathrm{E}$. Since the meaning of terms through A and E gradually become contradictory and minimised value, it was determined should there be an ability to define uyana with at least B level definitions. Therefore, the researchers chose commonly used 17 synonyms as shown in Table 1.

Table-1: Finding Synonyms for Park (Objective 1)

\begin{tabular}{|c|c|c|c|c|}
\hline $\mathbf{S} / \mathbf{N}$ & Synonym & Online Dictionary & Description & \\
\hline \multirow{2}{*}{1} & \multirow{2}{*}{ Arena } & \multirow{2}{*}{$\begin{array}{l}\text { (Cambridge English } \\
\text { Dictionary, 2020a) }\end{array}$} & $\begin{array}{l}\text { large, flat area surrounded by seats used } \\
\text { for sports or entertainment: }\end{array}$ & A specific place \\
\hline & & & an activity that involves argument and discussion & $\begin{array}{l}\text { Argument } \\
\text { Activity }\end{array}$ \\
\hline 2 & $\begin{array}{l}\text { Botanical } \\
\text { gardens }\end{array}$ & (Spencer \& Cross, 2016) & $\begin{array}{l}\text { A botanical garden or botanic garden is a garden dedicated } \\
\text { to the collection, cultivation, preservation and display of a } \\
\text { wide range of plants labelled with their botanical names. }\end{array}$ & A specific place \\
\hline \multirow{2}{*}{3} & \multirow{2}{*}{ Common } & $\begin{array}{l}\text { (Cambridge English } \\
\text { Dictionary, 2020c) }\end{array}$ & the same in a lot of places or for a lot of people & A specific place \\
\hline & & $\begin{array}{l}\text { (Merriam-Webster } \\
\text { Dictionary, 2020a) }\end{array}$ & $\begin{array}{l}\text { belonging to or shared by two or more individuals or } \\
\text { things or by all members of a group }\end{array}$ & Sharing \\
\hline 4 & $\begin{array}{l}\text { Country } \\
\text { Park }\end{array}$ & $\begin{array}{l}\text { (Macmillan Dictionary, } \\
\text { 2020a) }\end{array}$ & a large area of land in the country for people to visit & $\begin{array}{l}\text { Place people to } \\
\text { visit }\end{array}$ \\
\hline \multirow{6}{*}{5} & \multirow{6}{*}{ Court } & $\begin{array}{l}\text { (Cambridge English } \\
\text { Dictionary, 2020d) }\end{array}$ & $\begin{array}{l}\text { a place where trials and other legal cases happen, or } \\
\text { an area or a short road that is not covered by a roof }\end{array}$ & A specific place \\
\hline & & (Britannica, 2020) & $\begin{array}{l}\text { chamber, hall, building, or other place } \\
\text { where judicial proceedings are held }\end{array}$ & A specific place \\
\hline & & $\begin{array}{l}\text { (Merriam-Webster } \\
\text { Dictionary, 2020b) }\end{array}$ & an open space enclosed wholly or partly by buildings & A specific place \\
\hline & & (Dictionary.com, 2020a) & a place where justice is administered & A specific place \\
\hline & & $\begin{array}{l}\text { (Longman Dictionary, } \\
\text { 2020a) }\end{array}$ & an area made for playing games such as tennis & A specific place \\
\hline & & $\begin{array}{l}\text { (Macmillan Dictionary, } \\
\text { 2020b) }\end{array}$ & a place where trials take place and legal cases are decided & A specific place \\
\hline \multirow[t]{2}{*}{6} & \multirow[t]{2}{*}{ Estate } & $\begin{array}{l}\text { (Cambridge English } \\
\text { Dictionary, 2020e) }\end{array}$ & $\begin{array}{l}\text { a large area of land in the country which is owned by } \\
\text { a family or an organization and is often used } \\
\text { for growing crops or raising animals: } \\
\text { a group of houses or factories built in a planned way: }\end{array}$ & A specific place \\
\hline & & $\begin{array}{l}\text { (Merriam-Webster } \\
\text { Dictionary, 2020c) }\end{array}$ & a person's property in land and tenements & A specific place \\
\hline
\end{tabular}


K. Jayantha et al., Sch J Arts Humanit Soc Sci, May, 2021; 9(5): 144-157

\begin{tabular}{|c|c|c|c|c|}
\hline & & (Dictionary.com, 2020b) & interest, ownership, or property in land or other things. & A specific place \\
\hline & & $\begin{array}{l}\text { (Macmillan Dictionary, } \\
\text { 2020c) }\end{array}$ & The American word is development & Development \\
\hline & & $\begin{array}{l}\text { (OxfordLearnersDictionar } \\
\text { ies, 2020) }\end{array}$ & $\begin{array}{l}\text { an area of land with a lot of houses or factories of the same } \\
\text { type on it }\end{array}$ & A specific place \\
\hline & & $\begin{array}{l}\text { (Collins English } \\
\text { Dictionary, 2020a) } \\
\end{array}$ & $\begin{array}{l}\text { is all the money and property that they leave behind them } \\
\text { when they die. }\end{array}$ & Legal activity \\
\hline \multirow{4}{*}{7} & \multirow{4}{*}{ Field } & (Dictionary.com, 2020c) & $\begin{array}{l}\text { an expanse of open or cleared ground, especially a piece of } \\
\text { land suitable or used for pasture or tillage. } \\
\text { a piece of ground devoted to sports or contests; playing } \\
\text { field. }\end{array}$ & A specific place \\
\hline & & $\begin{array}{l}\text { (Cambridge English } \\
\text { Dictionary, 2020f) }\end{array}$ & $\begin{array}{l}\text { an area of land, used for growing crops or keeping animals, } \\
\text { usually surrounded by a fence: } \\
\text { an area, usually covered with grass, used for playing sports: }\end{array}$ & A specific place \\
\hline & & $\begin{array}{l}\text { (Merriam-Webster } \\
\text { Dictionary, 2020d) }\end{array}$ & $\begin{array}{l}\text { an open land area free of woods and buildings } \\
\text { land containing a natural resource }\end{array}$ & A specific place \\
\hline & & $\begin{array}{l}\text { (Macmillan Dictionary, } \\
\text { 2020d) }\end{array}$ & an area of land covered in grass and used for sport & A specific place \\
\hline \multirow{5}{*}{8} & \multirow{5}{*}{ Gardens } & (Dictionary.com, 2020d) & $\begin{array}{l}\text { a plot of ground, usually near a house, where flowers, } \\
\text { shrubs, vegetables, fruits, or herbs are cultivated. } \\
\text { a piece of ground or other space, commonly with } \\
\text { ornamental plants, trees, etc., used as a park or other public } \\
\text { recreation area: }\end{array}$ & A specific place \\
\hline & & $\begin{array}{l}\text { (Cambridge English } \\
\text { Dictionary, 2020g) }\end{array}$ & $\begin{array}{l}\text { a piece of land next to and belonging to a house, } \\
\text { where flowers and other plants are grown, and } \\
\text { often containing an area of grass: } \\
\text { a public park with flowers, plants, and places to sit: }\end{array}$ & A specific place \\
\hline & & \multirow{2}{*}{$\begin{array}{l}\text { (Merriam-Webster } \\
\text { Dictionary, 2020e) }\end{array}$} & $\begin{array}{l}\text { a plot of ground where herbs, fruits, flowers, or } \\
\text { vegetables are cultivated }\end{array}$ & A specific place \\
\hline & & & $\begin{array}{l}\text { a public recreation area or park usually ornamented with } \\
\text { plants and trees }\end{array}$ & A specific place \\
\hline & & $\begin{array}{l}\text { (Collins English } \\
\text { Dictionary, 2020b) }\end{array}$ & $\begin{array}{l}\text { an area of land used for the cultivation of ornamental plants, } \\
\text { etc., that is open to the public, sometimes part of a park }\end{array}$ & A specific place \\
\hline \multirow{6}{*}{9} & \multirow{6}{*}{ Green } & (Dictionary.com, 2020e) & $\begin{array}{l}\text { of the color of growing foliage, between yellow and blue in } \\
\text { the spectrum }\end{array}$ & A color \\
\hline & & (Cambridge English & of a color between blue and yellow; of the color of grass & A color \\
\hline & & Dictionary, 2020h) & an area planted with grass, especially for use by the public & A specific place \\
\hline & & (Merriam-Webster & consisting of green plants and usually edible herbage & A specific place \\
\hline & & Dictionary, 2020f) & a grassy plain or plot & A specific place \\
\hline & & $\begin{array}{l}\text { (Collins English } \\
\text { Dictionary, 2020c) }\end{array}$ & $\begin{array}{l}\text { A place that is green is covered with grass, plants, and trees } \\
\text { and not with houses or factories. }\end{array}$ & A specific place \\
\hline \multirow{5}{*}{10} & \multirow{5}{*}{ Grounds } & (Dictionary.com, 2020f) & the solid surface of the earth; firm or dry land & A specific place \\
\hline & & $\begin{array}{l}\text { (Cambridge English } \\
\text { Dictionary, 2020i) }\end{array}$ & land that surrounds a building & A specific place \\
\hline & & (Longman Dictionary, & an area of land without buildings, fences, woods etc. & A specific place \\
\hline & & $2020 \mathrm{~b})$ & the place where a particular sport is played & A specific place \\
\hline & & $\begin{array}{l}\text { (Collins English } \\
\text { Dictionary, 2020d) }\end{array}$ & the land around a dwelling house or other building & A specific place \\
\hline \multirow{4}{*}{11} & \multirow{4}{*}{ Pitch } & $\begin{array}{l}\text { (Collins English } \\
\text { Dictionary, 2020f) }\end{array}$ & $\begin{array}{l}\text { A pitch is an area of ground that is marked out and used for } \\
\text { playing a game such as football, cricket, or hockey. }\end{array}$ & A specific place \\
\hline & & $\begin{array}{l}\text { (Oxford Advanced } \\
\text { Learner's Dictionary, } \\
\text { 2020) }\end{array}$ & $\begin{array}{l}\text { an area of ground specially prepared and marked for playing } \\
\text { a sports game }\end{array}$ & A specific place \\
\hline & & $\begin{array}{l}\text { (Macmillan Dictionary, } \\
\text { 2020e) }\end{array}$ & a flat area of ground for playing sports on & A specific place \\
\hline & & $\begin{array}{l}\text { (Merriam-Webster } \\
\text { Dictionary, 2020h) }\end{array}$ & $\begin{array}{l}\text { to throw usually with a particular objective or toward a } \\
\text { particular point }\end{array}$ & A specific event \\
\hline \multirow{4}{*}{12} & \multirow{4}{*}{$\begin{array}{l}\text { Playgroun } \\
\text { d }\end{array}$} & (Dictionary.com, 2020h) & $\begin{array}{l}\text { an area used for outdoor play or recreation, especially by } \\
\text { children, and often containing recreational equipment such } \\
\text { as slides and swings }\end{array}$ & A specific place \\
\hline & & $\begin{array}{l}\text { (Cambridge English } \\
\text { Dictionary, 2020k) }\end{array}$ & $\begin{array}{l}\text { an area designed for children to play in outside, especially at } \\
\text { a school or in a park }\end{array}$ & A specific place \\
\hline & & $\begin{array}{l}\text { (Merriam-Webster } \\
\text { Dictionary, 2020i) }\end{array}$ & $\begin{array}{l}\text { a piece of land used for and usually equipped with } \\
\text { facilities for recreation especially by children }\end{array}$ & A specific place \\
\hline & & (Longman Dictionary, & an area for children to play, especially at a school or in & A specific place \\
\hline
\end{tabular}


K. Jayantha et al., Sch J Arts Humanit Soc Sci, May, 2021; 9(5): 144-157

\begin{tabular}{|c|c|c|c|c|}
\hline & & 2020c) & $\begin{array}{l}\text { a park, that often has } \\
\text { special equipment for climbing on, riding on etc }\end{array}$ & \\
\hline \multirow{3}{*}{16} & \multirow{3}{*}{ Square } & (Dictionary.com, 2020i) & a rectangle having all four sides of equal length. & A specific place \\
\hline & & $\begin{array}{l}\text { (Merriam-Webster } \\
\text { Dictionary, 2020j) }\end{array}$ & $\begin{array}{l}\text { an open place or area formed at the meeting of two or } \\
\text { more streets }\end{array}$ & A specific place \\
\hline & & $\begin{array}{l}\text { (Collins English } \\
\text { Dictionary, 2020g) }\end{array}$ & $\begin{array}{l}\text { a shape with four sides that are all the same length and } \\
\text { four corners that are all right angles. }\end{array}$ & A specific place \\
\hline \multirow{3}{*}{17} & \multirow{3}{*}{ Turf } & (Dictionary.com, 2020j) & a layer of matted earth formed by grass and plant roots. & A specific place \\
\hline & & $\begin{array}{l}\text { (Merriam-Webster } \\
\text { Dictionary, 2020k) }\end{array}$ & $\begin{array}{l}\text { the upper stratum of soil bound by grass and plant roots } \\
\text { into a thick mat }\end{array}$ & A specific place \\
\hline & & $\begin{array}{l}\text { (Collins English } \\
\text { Dictionary, 2020h) }\end{array}$ & $\begin{array}{l}\text { area which is most familiar to them or where } \\
\text { they feel most confident. }\end{array}$ & A specific place \\
\hline
\end{tabular}

Table-2: Finding Synonyms for Park Cont'd (Objective 2)

\begin{tabular}{|c|c|c|c|c|c|c|c|}
\hline \multirow{4}{*}{$\mathbf{S} / \mathbf{N}$} & \multirow{4}{*}{ Synonyms } & \multicolumn{3}{|c|}{ Who does Go? } & \multirow{4}{*}{$\begin{array}{l}\text { Where does } \\
\text { Go? } \\
\text { Specific Land } \\
\text { Area }\end{array}$} & \multirow{4}{*}{$\begin{array}{l}\text { Why does } \\
\text { Go? } \\
\text { Physical and } \\
\text { Mental } \\
\text { Recreation }\end{array}$} & \multirow{4}{*}{$\begin{array}{l}\text { Park } \\
\text { Yes/No }\end{array}$} \\
\hline & & \multirow{2}{*}{\multicolumn{2}{|c|}{$\begin{array}{l}\text { Original Nature } \\
\text { Uththama }\end{array}$}} & \multirow{3}{*}{$\begin{array}{l}\text { Secondary } \\
\text { Nature } \\
\text { Specific } \\
\text { Population }\end{array}$} & & & \\
\hline & & & & & & & \\
\hline & & Secular & Worldly & & & & \\
\hline 01 & Arena & No & No & No & Yes & No & No \\
\hline 02 & Botanical Gardens & No & No & Yes & Yes & $1 / 2$ Yes & $1 / 2$ Yes \\
\hline 03 & Common & No & No & No & Yes & No & No \\
\hline 04 & Country Park & No & No & Yes & Yes & Yes & Yes \\
\hline 05 & Court & No & No & $1 / 2$ Yes & Yes & $1 / 2$ Yes & $1 / 2$ Yes \\
\hline 06 & Estate & No & No & No & Yes & No & No \\
\hline 07 & Field & No & No & No & Yes & No & No \\
\hline 08 & Gardens & Yes & Yes & Yes & Yes & Yes & Yes \\
\hline 09 & Green & No & No & No & Yes & No & No \\
\hline 10 & Grounds & No & No & No & Yes & No & No \\
\hline 11 & Pitch & No & No & Yes & Yes & $1 / 2$ Yes & $1 / 2$ Yes \\
\hline 12 & Playground & No & Yes & Yes & Yes & $1 / 2$ Yes & $1 / 2$ Yes \\
\hline 13 & Recreational area & Yes & Yes & Yes & Yes & Yes & Yes \\
\hline 14 & Sports field & No & Yes & Yes & Yes & $1 / 2$ Yes & $1 / 2$ Yes \\
\hline 15 & Sports ground & No & Yes & Yes & Yes & $1 / 2$ Yes & $1 / 2$ Yes \\
\hline 16 & Square & No & No & No & Yes & No & No \\
\hline 17 & Turf & No & No & No & Yes & No & No \\
\hline
\end{tabular}

According to Table 2, we considered 17 terms that are almost synonymous with the word park. It should be noted, however, that the definition of those terms has not been sought to be considered in the original definition or the nirukthi. Therefore, there may be errors in these definitions. Because most of the definitions received might either be a description or an interpretation. Out of the 17 words, only the definitions for Country Park and recreational area were seemed to be like the definition of uyana/ park. Where country people visit to obtain physical and mental wellbeing is a country park. Where people go for physical and mental recreation is a recreational area. In addition, Botanical Gardens, Court, Pitch, Playground, Sports field, and Sports ground were partially like the definition of uyana. However, when the use of these parks is investigated it was found that the role and functions of these parks were quite distant from its definition. That happens because these parks do not operate by considering the original definition. Should there be an attention to the base word most of the definitions of these parks would be fully like the definition of uyana. In addition, as it is not associated with the definition of the base word the following of words such as Arena, Common, Estate, Field, Green, Grounds, Square and Turf cannot be recommended to use as definitions for the term uyana/ park.

\section{Measuring the power of definitions}

To measure the power of definitions, 14 words were selected through 09 dictionaries and different organisations. The basic idea of those definitions, the level of definition and its power were calculated using the following formula introduced through a previous publication (Jayantha, Ariyawansa, et al., 2020b).

$$
\begin{aligned}
& \mathrm{A}=100 / \mathrm{A}_{\mathrm{n}} \\
& \mathrm{B}=\mathrm{A} / \mathrm{B}_{\mathrm{n}} \\
& \mathrm{C}=\mathrm{B} / \mathrm{C}_{\mathrm{n}} \\
& \mathrm{D}=\mathrm{C} / \mathrm{D}_{\mathrm{n}} \text { where } \mathrm{A}=\text { Base word, } \mathrm{B}=\text { Level } 2, \mathrm{C}=\text { Level } \\
& 3, \mathrm{D}=\text { Level } 4 \text { and } \mathrm{n}=\text { number of pure synonyms. }
\end{aligned}
$$


Table-3: Definitions Made by Experts for the Concept 'Park' (Objective 3)

\begin{tabular}{|c|c|c|c|c|c|}
\hline $\mathbf{S} / \mathbf{N}$ & Ref. & Definition & The Idea & Level & Power \\
\hline 1 & $\begin{array}{l}\text { 1.1. UNESCO Global } \\
\text { Geopark (United Nations } \\
\text { Educational, 2020) }\end{array}$ & $\begin{array}{l}\text { UNESCO Global Geoparks are single, unified } \\
\text { geographical areas where sites and landscapes } \\
\text { of international geological significance are } \\
\text { managed with a holistic concept of protection, } \\
\text { education, and sustainable development. }\end{array}$ & Statement & $\mathrm{D}$ & 0.0015 \\
\hline 2 & $\begin{array}{l}\text { Recreation and Park } \\
\text { Association (CT } \\
\text { Recreation and Parks } \\
\text { Association, 2021) }\end{array}$ & $\begin{array}{l}\text { A public park is any area or portions of areas } \\
\text { dedicated or designated by any federal, state, } \\
\text { or local agency primarily for public } \\
\text { recreational use. }\end{array}$ & Description & $\mathrm{B}$ & 12.5 \\
\hline 3 & $\begin{array}{l}\text { Scrabble World Solver } \\
\text { (Scrabble Word Solver } \\
\text { and Dictionary, 2020) }\end{array}$ & $\begin{array}{l}\text { a large area of land preserved in its natural } \\
\text { state as public property; "there are laws that } \\
\text { protect the wildlife in this park" }\end{array}$ & Explanation & B & 12.5 \\
\hline 4 & $\begin{array}{l}\text { Scrabble World Solver } \\
\text { (Scrabble Word Solver } \\
\text { and Dictionary, 2020) }\end{array}$ & $\begin{array}{l}\text { a piece of open land for recreational use in an } \\
\text { urban area; "they went for a walk in the park" }\end{array}$ & Description & B & 12.5 \\
\hline 5 & $\begin{array}{l}\text { urbandictionary.com } \\
\text { (Urban Dictionary, 2019) }\end{array}$ & $\begin{array}{l}\text { A park is a common place where people go to } \\
\text { walk, play, or catch the sun. It's normally } \\
\text { a playground for younger children. }\end{array}$ & Clarification & $\mathrm{C}$ & 0.2841 \\
\hline 6 & $\begin{array}{l}\text { National Park (National } \\
\text { Parks UK, 2021) }\end{array}$ & $\begin{array}{l}\text { National Parks welcome visitors and } \\
\text { provide opportunities for everyone to } \\
\text { experience, enjoy and learn about their } \\
\text { special qualities. }\end{array}$ & Explanation & B & 12.5 \\
\hline 7 & $\begin{array}{l}\text { Encyclopaedia } \\
\text { Britannica } \\
\text { (Encyclopædia } \\
\text { Britannica, 2020) } \\
\end{array}$ & $\begin{array}{l}\text { National park, an area set aside by a national } \\
\text { government for the preservation of the } \\
\text { natural environment }\end{array}$ & Clarification & $\mathrm{C}$ & 0.2841 \\
\hline 8 & $\begin{array}{l}\text { merriam-webster.com } \\
\text { (Merriam-Webster } \\
\text { Dictionary, 2020g) }\end{array}$ & $\begin{array}{l}\text { an enclosed piece of ground stocked with } \\
\text { game and held by royal prescription or grant }\end{array}$ & Clarification & $\mathrm{C}$ & 0.2841 \\
\hline 9 & $\begin{array}{l}\text { dictionary.com } \\
\text { (Dictionary.com, 2020g) }\end{array}$ & $\begin{array}{l}\text { an area of land, usually in a largely natural } \\
\text { state, for the enjoyment of the public, having } \\
\text { facilities for rest and recreation, often owned, } \\
\text { set apart, and managed by a city, state, or } \\
\text { nation. }\end{array}$ & Explanation & B & 12.5 \\
\hline 10 & $\begin{array}{l}\text { dictionary.cambridge.org } \\
\text { (Cambridge English } \\
\text { Dictionary, 2020j) }\end{array}$ & $\begin{array}{l}\text { a large area of land with grass and trees, } \\
\text { usually surrounded by fences or walls, } \\
\text { and specially arranged so } \\
\text { that people can walk in it } \\
\text { for pleasure or children can play in it: }\end{array}$ & Clarification & $\mathrm{C}$ & 0.2841 \\
\hline 11 & $\begin{array}{l}\text { collinsdictionary.com } \\
\text { (Collins English } \\
\text { Dictionary, 2020e) } \\
\end{array}$ & $\begin{array}{l}\text { A park is a public area of land with grass and } \\
\text { trees, usually in a town, where people go in } \\
\text { order to relax and enjoy themselves. }\end{array}$ & Clarification & $\mathrm{C}$ & 0.2841 \\
\hline 12 & $\begin{array}{l}\text { yourdictionary.com } \\
\text { (Your Dictionary, 2020a) }\end{array}$ & $\begin{array}{l}\text { The definition of a park is an area of land } \\
\text { used for various purposes such as recreation, } \\
\text { playgrounds, and swimming. }\end{array}$ & Description & B & 12.5 \\
\hline 13 & $\begin{array}{l}\text { lexico.com (Oxford } \\
\text { Dictionary, 2020) }\end{array}$ & $\begin{array}{l}\text { A large public garden or area of land used for } \\
\text { recreation. }\end{array}$ & Description & B & 12.5 \\
\hline 14 & $\begin{array}{l}\text { thefreedictionary.com } \\
\text { (The Free Dictionary, } \\
\text { 2020) }\end{array}$ & $\begin{array}{l}\text { A piece of land with few or no buildings withi } \\
\mathrm{n} \text { or adjoining a town, maintained for recreati } \\
\text { onal and ornamental purposes. }\end{array}$ & Description & B & 12.5 \\
\hline
\end{tabular}

Using the suggested formula, it was able to calculate the power of synonyms provided to the term park by different levels. Power of level A was 100 when power of level $\mathrm{B}=12.5$, power of level $\mathrm{C}=$ 0.284091 and power of level $\mathrm{D}=0.001449$. Using the expertise knowledge, it was found that out of 14 definitions on park 08 belonged to level $\mathrm{B}$ and 05 belonged to level $\mathrm{C}$. There was one definition from level D. Among 14 selected definitions, there was not any definition from level $A$. These results also confirmed that there was no definition, which used to express the meaning of the base term.

Method of categorising the concept of park / Uyana

Data were collected from internet where the term 'park' is used in different places. In the highest 
K. Jayantha et al., Sch J Arts Humanit Soc Sci, May, 2021; 9(5): 144-157

sense (according to hela nirukthi method) 'U' of uyana was considered as loukika and lookoththara. In the highest sense of loukika 'U' was identified as "it" or "they".

Table-4: Categorization of Park (Objective 4)

\begin{tabular}{|c|c|c|c|c|c|c|c|}
\hline \multirow{4}{*}{$\mathbf{s} / \mathbf{n}$} & \multirow{4}{*}{ Ref } & \multirow{4}{*}{$\begin{array}{l}\text { Name of } \\
\text { park }\end{array}$} & \multicolumn{5}{|c|}{ Nirukthi Meaning } \\
\hline & & & \multicolumn{3}{|c|}{ By People's Sense } & \multicolumn{2}{|c|}{$\begin{array}{l}\text { By Non-People's } \\
\text { Sense }\end{array}$} \\
\hline & & & \multicolumn{2}{|c|}{$\begin{array}{l}\text { According to Uththama } \\
\text { Meaning }\end{array}$} & \multirow{2}{*}{$\begin{array}{l}\text { According } \\
\text { to U/ Un } \\
\text { Meaning }\end{array}$} & \multirow{2}{*}{$\begin{array}{l}\text { What is } \\
\text { 'there' } \\
\text { Sense }\end{array}$} & \multirow{2}{*}{$\begin{array}{l}\text { What is } \\
\text { 'name' } \\
\text { Sense }\end{array}$} \\
\hline & & & $\begin{array}{l}\text { Secular } \\
\text { Uththama }\end{array}$ & $\begin{array}{l}\text { Worldly } \\
\text { Uththama }\end{array}$ & & & \\
\hline 1 & $\begin{array}{l}\text { Mahamewuna Uyana } \\
\text { (Pemaratana, 2001) }\end{array}$ & $\begin{array}{l}\text { Mahamewuna } \\
\text { Uyana }\end{array}$ & $X$ & & & & \\
\hline 2 & $\begin{array}{l}\text { Ranmasu Uyana (Pemaratana, } \\
\text { 2001) }\end{array}$ & $\begin{array}{l}\text { Ranmasu } \\
\text { Uyana }\end{array}$ & & $\mathrm{X}$ & & & \\
\hline 3 & Lamaa Uyana & Lamaa Uyana & & & $\mathrm{X}$ & & \\
\hline 4 & $\begin{array}{l}\text { National Park (Britannica, } \\
\text { 2021) }\end{array}$ & National Park & & & $X$ & & \\
\hline 5 & Urban Park (ArchDaily, 2020) & Urban Park & & & $\mathrm{X}$ & & \\
\hline 6 & $\begin{array}{l}\text { National Naa Mal Uyana } \\
\text { (Central Cultural Fund, 2021) }\end{array}$ & $\begin{array}{l}\text { National Naa } \\
\text { Mal Uyana }\end{array}$ & & & $X$ & & \\
\hline 7 & $\begin{array}{l}\text { Car Park (Cambridge English } \\
\text { Dictionary, 2020b) }\end{array}$ & Car Park & & & & $\mathrm{X}$ & \\
\hline 8 & $\begin{array}{l}\text { Industrial Park (Cambridge } \\
\text { English Dictionary, 2020b) }\end{array}$ & $\begin{array}{l}\text { Industrial } \\
\text { Park }\end{array}$ & & & & $\mathrm{X}$ & \\
\hline 9 & Mr. ABC Park (Chris, 2021) & Mr. ABC Park & & & & & $\mathrm{X}$ \\
\hline
\end{tabular}

According to this classification, things that are used in the meaning of 'park' is classified into two main meanings. 1. People's sense and 2. Non-people sense. The meaning of the peoples' sense is also categorized into two such as uththama sense and sense of a particular group of people. The classification of uththama is the oldest or the oldest classification with at least 2600 years old history (Jayantha et al., 2021; Jayantha, RG, et al., 2020). This same old classification is dualistic. That is, the secular noble and the worldly noble. Clear examples of this classification can be found in Sri Lanka. The distinctive feature of this is that the definition of uyana can be found through the secular noble categorization. Mahamevuna Uyana is a perfect example to understand this.

The most important difference, however, was that the parks used in the Worldly or Loukika sense of the past was no longer used in the existing sense. There are now the only archaeological ruins left. An example of this is the Ranmasu Uyana. The concept of the secular elite has been transformed by modern political nation. This may be because the elite of the feudal period were displaced by the wealthy class in the face of the capitalist socio-economic environment. In this new political environment, the moneyed class is often seen as elite or noble. Thus, the basic definition of treating a particular place as a park/ uyana is not violated even in the new political environment. Similarly, the definition of the park as a lamaa uyana (children's park) has not been violated. So, the word lamaa uyana means lamaa+un+yana. Similarly, the meaning of the National Park is also consistent with the original definition of the uyana. That is, it is possible to define the National Park in a way that does not harm the original definition of what the nation is. Similarly, the term municipal park does not harm the definition of the term park. There are also instances where the concept of uyana/ park is used in a non-personal sense. There are two main categories of this non-personal category. That is, what is there and what's in a person's name. There have been occasions when the concept of uyana has been applied to a particular species of tree. For example, National Namal Uyana can be used as an example. But even here, the basic definition of a park is clear. The term 'national' means "they" or "un". Meaning is that this place is generally open to the public. Term Naamal gives an idea of what consists in that place.

There were occasions when the concept of a uyana was applied to a particular type of industry. The industrial park for example. There have also been instances where the concept of a uyana has been used to temporarily park certain objects. Take for example a car park. However, this type of uyana can only be used in a way that is out of the original meaning. This type of garden does not match the root definition of uyana. The concept of uyana is defined as the place where a particular group of people go by themselves to achieve physical and mental wellbeing. In that sense, it is necessary to point out why a given cell is a living entity to fulfill the meaning of uyana. The concept of a uyana based on non-living objects does not meet the basic 
K. Jayantha et al., Sch J Arts Humanit Soc Sci, May, 2021; 9(5): 144-157

definition of uyana such as trees, industries, or vehicles. There was also an occasion found where the term uyana/ park used as a name. South Korea has Park as a surname and other countries also use park as either a name or a surname. This is also clearly out of the concept of uyana and can be considered as a special circumstance.

\section{CONCLUSION}

There is diverse range of terms used as a synonym to park/ 'Uyana'. The concept of 'Uyana' can be analyzed according to Hela Nirukthi method. This Nirukthi Patha Sutta is essential to obtain examples when practicing hela nirukthi method specially focused on Swakaaya. It is in this sense that the concept of uyana has emerged considering the term uthuman. There are two types of uyana for two types of uththaman to go. It means that there was uyana for the secular world and the uyana for the worldly worlds. In the present world sense, the meaning what appears to be of $U$ in uyana slightly different. Later it was used to define any category of population (uthuman) and the yana was defined as "go". Thus, uyana or park is a place where a specific type of population goes with a noble intention, which is to obtain physical and mental wellbeing. Yet some of the definitions of those that use the term 'park' has not been sought to be considered in the original definition of uyana. Therefore, there may be errors in these definitions. Because most of the definitions might either be a description or an interpretation that is distant from the original meaning of uyana. This was proved through this study by showing that there was no definition from level A among 14 selected definitions for 'park' in this study.

\section{REFERENCES}

- Acharya, K. (2002). Buddhaanusm.rti - A Glossary of Buddhist Terms. Somaiya Publications. http://ccbs.ntu.edu.tw/DBLM/resource/ebooks/10294 6/102946.htm

- Addison Park District. (2017). Park \& Recreation Comprehensive Master Plan Classification of Parks.

- Alonso González Peterhouse, P. (2011). What is a Cultural Park? http://digital.csic.es/bitstream/10261/126390/1/Preser ving_the_future_projecting_the_pas.pdf

- Amarasinghe, J. (2020, April 3). ravana king. Maha Ravanayanaya Web Page. http://ravana.yolasite.com/history-sri-lnka.php

- AmazingLanka.com. (2020, April 3). Sakwala Chakraya or the Stargate of Ranmasu Uyana . AmazingLanka Web Page. https://amazinglanka.com/wp/sawala-chakraya/

- ArchDaily. (2020, November 10). Urban Park. ArchDaily. https://www.archdaily.com/tag/urban-park

- Aung-Thwin, M. A. (2005). The Mists of Rāmañña: The Legend that was Lower Burma (illustrated). University of Hawai'i Press.

- Bai, H., Stanis, S. A. W., Kaczynski, A. T., \& Besenyi, G. M. (2013). Perceptions of neighborhood park quality: Associations with physical activity and body mass index. Annals of Behavioral Medicine, 45(SUPPL.1). https://doi.org/10.1007/s12160-0129448-4

- Britannica. (2020). court | Definition, Functions, Structure, \& Facts. Britannica. https://www.britannica.com/topic/court-law

- Britannica. (2021). national park | Definition, History, \& Famous National Parks. Britannica. https://www.britannica.com/science/national-park

- Buddha Jayanthi Thripitakaya. (n.d.). (Nirukthipatha

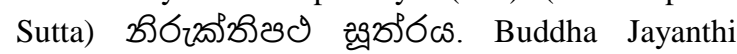
Thripitakaya (Online). Retrieved 4 April 2021, from https://www.thripitakaya.org/tipitakaya/Index/114?s= 1117

- Cambridge English Dictionary. (2020a). ARENA | meaning in the Cambridge English Dictionary. Cambridge English Dictionary. https://dictionary.cambridge.org/dictionary/english/ar ena

- $\quad$ Cambridge English Dictionary. (2020b). CAR PARK meaning. Cambridge English Dictionary. https://dictionary.cambridge.org/dictionary/english/ca r-park

- Cambridge English Dictionary. (2020c). COMMON | meaning in the Cambridge English Dictionary. Cambridge English Dictionary. https://dictionary.cambridge.org/dictionary/english/co mmon

- Cambridge English Dictionary. (2020d). COURT | meaning. Cambridge English Dictionary. https://dictionary.cambridge.org/dictionary/english/co urt

- Cambridge English Dictionary. (2020e). ESTATE | meaning. Cambridge English Dictionary. https://dictionary.cambridge.org/dictionary/english/est ate $\mathrm{q}=$ Estate

- Cambridge English Dictionary. (2020f). FIELD | meaning. Cambridge English Dictionary. https://dictionary.cambridge.org/dictionary/english/fie ld

- Cambridge English Dictionary. (2020g). GARDEN | meaning. Cambridge English Dictionary. https://dictionary.cambridge.org/dictionary/english/ga rden

- Cambridge English Dictionary. (2020h). GREEN | meaning. Cambridge English Dictionary. https://dictionary.cambridge.org/dictionary/english/gr een

- Cambridge English Dictionary. (2020i). GROUNDS | meaning. Cambridge English Dictionary. https://dictionary.cambridge.org/dictionary/english/gr ounds

- Cambridge English Dictionary. (2020j). PARK | meaning. Cambridge English Dictionary. https://dictionary.cambridge.org/dictionary/english/pa rk

- Cambridge English Dictionary. (2020k). PLAYGROUND | meaning. Cambridge English Dictionary.

https://dictionary.cambridge.org/dictionary/english/pl ayground 
K. Jayantha et al., Sch J Arts Humanit Soc Sci, May, 2021; 9(5): 144-157

- Central Cultural Fund. (2021). Namal Uyana. Central Cultural Fund, Sri Lanka. https://ccf.gov.lk/index.php?option=com_content\&vie $\mathrm{w}=$ article \&id $=175 \&$ Itemid $=240 \&$ lang $=\mathrm{en}$

- Cesário, V., Petrelli, D., \& Nisi, V. (2020, April 21). Teenage Visitor Experience: Classification of Behavioral Dynamics in Museums. Conference on Human Factors in Computing Systems - Proceedings. https://doi.org/10.1145/3313831.3376334

- Charney, M. W. (2006). Powerful Learning: Buddhist Literati and the Throne in Burma's Last Dynasty, 1752-1885. University of Michigan.

- Chris, A. (2021, March 5). 25+ Famous Parks | Notable People With the Last Name Park. Ranker. https://www.ranker.com/list/famous-people-whoselast-name-is-park/chris-abraham

- Collins English Dictionary. (2020a). Estate definition and meaning. Collins English Dictionary. https://www.collinsdictionary.com/dictionary/english/ estate

- Collins English Dictionary. (2020b). Gardens definition and meaning. Collins English Dictionary. https://www.collinsdictionary.com/dictionary/english/ gardens

- Collins English Dictionary. (2020c). Green definition and meaning. Collins English Dictionary. https://www.collinsdictionary.com/dictionary/english/ green

- Collins English Dictionary. (2020d). Grounds definition and meaning. Collins English Dictionary. https://www.collinsdictionary.com/dictionary/english/ grounds

- Collins English Dictionary. (2020e). Park definition and meaning. Collins English Dictionary. https://www.collinsdictionary.com/dictionary/english/ park

- Collins English Dictionary. (2020f). Pitch definition and meaning . Collins English Dictionary. https://www.collinsdictionary.com/dictionary/english/ pitch

- Collins English Dictionary. (2020g). Square definition and meaning. Collins English Dictionary. https://www.collinsdictionary.com/dictionary/english/ square

- Collins English Dictionary. (2020h). Turf definition and meaning. Collins English Dictionary. https://www.collinsdictionary.com/dictionary/english/ turf

- Cousins, L. S. (1996). The dating of the historical Buddha: A review article. Journal of the Royal Asiatic Society, $6(1)$ 57-63. https://doi.org/10.1017/s1356186300014760

- CT Recreation and Parks Association. (2021). What is Parks and Recreation? CT Recreation and Parks Association. http://crpa.com/resources/what-is-parksand-recreation

- Dalley, S. (1993). Ancient Mesopotamian Gardens and the Identification of the Hanging Gardens of Babylon Resolved (Vol. 21, Issue 1). https://about.jstor.org/terms

- Dalley, S. (2013). The Mystery of the Hanging Garden of Babylon. In Oxford University Press.
Oxford University Press. https://global.oup.com/academic/product/the-mysteryof-the-hanging-garden-of-babylon9780198728849? $\mathrm{cc}=\mathrm{hk} \&$ lang $=\mathrm{en} \&$

- Dictionary.com. (2020a). Court | Definition of Court. Dictionary.Com.

https://www.dictionary.com/browse/court

- Dictionary.com. (2020b). Estate | Definition of Estate. Dictionary.Com.

https://www.dictionary.com/browse/estate?s=t

- Dictionary.com. (2020c). Field | Definition of Field. Dictionary.Com.

https://www.dictionary.com/browse/field?s=t

- Dictionary.com. (2020d). Garden | Definition of Garden. Dictionary.Com. https://www.dictionary.com/browse/gardens?s=t

- Dictionary.com. (2020e). Green | Definition of Green. Dictionary.Com.

https://www.dictionary.com/browse/green?s=t

- Dictionary.com. (2020f). Ground | Definition of Ground. Dictionary.Com. https://www.dictionary.com/browse/grounds?s=t

- Dictionary.com. (2020g). Park | Definition of Park. Dictionary.Com.

https://www.dictionary.com/browse/park

- Dictionary.com. (2020h). Playground | Definition of Playground. Dictionary.Com. https://www.dictionary.com/browse/playground?s=t

- Dictionary.com. (2020i). Square | Definition of Square. Dictionary.Com. https://www.dictionary.com/browse/square?s=t

- Dictionary.com. (2020j). Turf | Definition of Turf. Dictionary.Com.

https://www.dictionary.com/browse/turf\#

- Encyclopædia Britannica. (2020). Prince Edward Island National Park . Encyclopædia Britannica, Inc. https://www.britannica.com/place/Prince-EdwardIsland-National-Park

- $\quad$ Epstein, L. H., Raja, S., Gold, S. S., Paluch, R. A., Pak, Y., \& Roemmich, J. N. (2006). Reducing sedentary behavior: The relationship between park area and the physical activity of youth. Psychological Science, 17(8), 654-659. https://doi.org/10.1111/j.1467-9280.2006.01761.x

- Fleet, J. F. (1906). The Tradition about the Corporeal Relics of Buddha. In Source: The Journal of the Royal Asiatic Society of Great Britain and Ireland. https://about.jstor.org/terms

- Gies, E. (2006). The Health Benefits of Parks How Parks Help Keep Americans and Their Communities Fit and Healthy. www.tpl.org

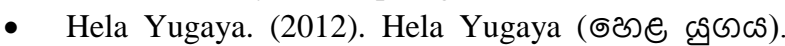
Hela Yugaya Blog. http://helayugaya.blogspot.com/search/label/बचेßిఠว ณฉ นึวดฉ ?\&max-results=2

- Herath, H. M. S. B. (2018a). Scholars Journal of Arts, Humanities and Social Sciences A Historical Study on Forts and Gravets Usage of Ceylonese. https://doi.org/10.21276/sjahss.2018.6.8.2

- Herath, H. M. S. B. (2018b). Scholars Journal of Arts, Humanities and Social Sciences Hidden Objectives of 
K. Jayantha et al., Sch J Arts Humanit Soc Sci, May, 2021; 9(5): 144-157

Frederick North's Treaty and the 1803 Victory of British Protest Battle in Ceylon. https://doi.org/10.21276/sjahss.2018.6.3.25

- Houtart, F. (1976). Buddhism and Politics in SouthEast Asia: Part One. In Scientist (Vol. 5, Issue 3). https://about.jstor.org/terms

- Idris, M. Y. I., Leng, Y. Y., Tamil, E. M., Noor, N. M., \& Razak, Z. (2009). Car park system: A review of smart parking system and its technology. In Information Technology Journal (Vol. 8, Issue 2, pp. 101-113). https://doi.org/10.3923/itj.2009.101.113

- Indira Gandhi National Center for the Arts. (2020). Kassapa Buddha. Indira Gandhi National Center for the Arts. http://ignca.gov.in/online-digitalresources/jataka-stories/102-kassapa-buddha/

- Jayantha, K., Ariyawansa, R., \& Anura Kumara, U. (2020a). Sustainability: Definitions Vs Interpretations. International Journal of Scientific and Research Publications, $10(9), \quad 334$. https://doi.org/10.29322/IJSRP.10.09.2020.p10539

- Jayantha, K., Ariyawansa, R. G., \& Anura Kumara, U. (2020b). Which Definition Should We Select? Power of Definitions. European Journal of Social Sciences, 60(4),

285-301. http://www.europeanjournalofsocialsciences.com/

- Jayantha, K., Ariyawansa, R. G., \& Kumara, U. A. (2021). SWA+BHAAWA (NATURE): DEFINITION AND UNDERSTANDING. European Journal of Social Sciences $\quad$ Studies, https://doi.org/10.46827/ejsss.v6i2.1011

- Jayantha, K., RG, A., \& U, A. K. (2020). Sustainability: Definitions Vs Interpretations. International Journal of Scientific and Research Publications (IJSRP), 10(9), 334-341. https://doi.org/10.29322/ijsrp.10.09.2020.p10539

- Joung, H. M., \& Park-Poaps, H. (2013). Factors motivating and influencing clothing disposal behaviours. International Journal of Consumer Studies, 37(1), 105-111. https://doi.org/10.1111/j.1470-6431.2011.01048.x

- Kaczynski, A. T., Besenyi, G. M., Stanis, S. A. W., Koohsari, M. J., Oestman, K. B., Bergstrom, R., Potwarka, L. R., \& Reis, R. S. (2014). Are park proximity and park features related to park use and park-based physical activity among adults? Variations by multiple socio-demographic characteristics. International Journal of Behavioral Nutrition and Physical Activity, 11(1), 146. https://doi.org/10.1186/s12966-014-0146-4

- Khomsi, M., \& Lapointe, D. (2010). Visitor's satisfaction measurement in animal parks: The case of Parc Safari in Québec, Canada. OURISMOS: AN INTERNATIONAL MULTIDISCIPLINARY JOURNAL OF TOURISM, 11(4). https://www.researchgate.net/publication/317045049_ Visitor's_satisfaction_measurement_in_animal_parks _The_case_of_Parc_Safari_in_Quebec_Canada

- Kim, S., \& Kyu Park, C. (2007). Basic garment pattern generation using geometric modeling method. International Journal of Clothing Science and Technology, 19(1), 7-17. https://doi.org/10.1108/09556220710717017
- Krystek, L. (2010). The Seven Wonders - Hanging Gardens of Babylon. Http://Www.Unmuseum.Org/. http://www.unmuseum.org/hangg.htm

- Lexico.com. (2020). PARK | Synonyms of PARK. Oxford Dictionary on Lexico.Com. https://www.lexico.com/synonyms/park

- Lieberman, V. (1986). How Reliable is U Kala's Burmese Chronicle? Some New Comparisons. Journal of Southeast Asian Studies, 17(2), 236-255. https://doi.org/10.1017/S002246340000103X

- Liyanagamage, A., \& Gunawadana, R. (1987). Anuradhapura Yugaya (3rd ed.). National Library Sevice Board.

- Longman Dictionary. (2020a). court | meaning of court. Longman Dictionary. https://www.ldoceonline.com/dictionary/court

- Longman Dictionary. (2020b). ground | meaning of ground. Longman Dictionary of Contemporary English.

https://www.ldoceonline.com/dictionary/ground

- Longman Dictionary. (2020c). playground | meaning of playground. Longman Dictionary of Contemporary English https://www.ldoceonline.com/dictionary/playground

- Macmillan Dictionary. (2020a). COUNTRY PARK (noun) definition and synonyms . Macmillan Dictionary.

https://www.macmillandictionary.com/dictionary/briti sh/country-park

- Macmillan Dictionary. (2020b). COURT (noun) definition and synonyms. Macmillan Dictionary. https://www.macmillandictionary.com/dictionary/briti sh/court_1

- Macmillan Dictionary. (2020c). ESTATE (noun) definition and synonyms. Macmillan Dictionary. https://www.macmillandictionary.com/dictionary/briti sh/estate

- Macmillan Dictionary. (2020d). FIELD (noun) definition and synonyms. Macmillan Dictionary. https://www.macmillandictionary.com/dictionary/briti sh/field_1

- Macmillan Dictionary. (2020e). PITCH (noun) definition and synonyms . Macmillan Dictionary. https://www.macmillandictionary.com/dictionary/briti sh/pitch_1

- Macmillan Thesaurus. (2020). park synonyms with definition. Macmillan Thesaurus. https://www.macmillanthesaurus.com/park

- Mansor, M., Zakariya, K., \& Harun, N. Z. (2019). Challenges on use of recreational parks in Kuala Lumpur. Journal of Construction in Developing Countries, 24(1), 141-162. https://doi.org/10.21315/jcdc2019.24.1.8

- Martin, S., Weitz, K., Cushman, R., Sharma, A., Lindrooth, R., \& Moran, S. (1996). Eco-Industrial Parks: A Case Study and Analysis of Economic, Environmental, Technical, and Regulatory Issues. Institute of Portland Metropolitan Studies Publications.

https://pdxscholar.library.pdx.edu/metropolitianstudie $\mathrm{s} / 110$ 
- Merriam-Webster Dictionary. (2020a). Common | Definition of Common. Merriam-Webster Dictionary. https://www.merriamwebster.com/dictionary/common

- Merriam-Webster Dictionary. (2020b). Court | Definition of Court. Merriam-Webster Dictionary. https://www.merriam-webster.com/dictionary/court

- Merriam-Webster Dictionary. (2020c). Estate Definition of Estate. Merriam-Webster Dictionary. https://www.merriam-webster.com/dictionary/estate

- Merriam-Webster Dictionary. (2020d). Field Definition of Field. Merriam-Webster Dictionary. https://www.merriam-webster.com/dictionary/field

- Merriam-Webster Dictionary. (2020e). Gardens | Definition of Gardens. Merriam-Webster Dictionary. https://www.merriam-webster.com/dictionary/gardens

- Merriam-Webster Dictionary. (2020f). Green | Definition of Green . Merriam-Webster Dictionary. https://www.merriam-webster.com/dictionary/green

- Merriam-Webster Dictionary. (2020g). Park | Definition of Park. Merriam-Webster Dictionary. https://www.merriam-webster.com/dictionary/park

- Merriam-Webster Dictionary. (2020h). Pitch | Definition of Pitch. Merriam-Webster. https://www.merriam-webster.com/dictionary/pitch

- Merriam-Webster Dictionary. (2020i). Playground | Definition of Playground. Merriam-Webster Dictionary. https://www.merriamwebster.com/dictionary/playground

- Merriam-Webster Dictionary. (2020j). Square | Definition of Square. Merriam-Webster Dictionary. https://www.merriam-webster.com/dictionary/square

- Merriam-Webster Dictionary. (2020k). Turf | Definition of Turf. Merriam-Webster Dictionary. https://www.merriam-webster.com/dictionary/turf

- Merriam-Webster Thesaurus. (2020). Park Synonyms. Merriam-Webster Thesaurus. https://www.merriamwebster.com/thesaurus/park

- National Parks and Wildlife Service. (2015). What is a national park? Stage 2 HSIE - Teacher's Guide. In Office of Environment and Heritage. https://www.google.com/search?q=What+is+a+nation al+park $\% 3 \mathrm{~F}+$ Stage $+2+\mathrm{HSIE}+-$

+ Teacher's+Guide $+(2015)+$ National+Parks+and + Wil dlife+Service $\% 2 \mathrm{C}+$ Office+of+Environment+and+Her itage $\% 2 \mathrm{C}+$ nationalparks.nsw.gov.au\&rlz $=1 \mathrm{C} 1 \mathrm{EJFC}$ enLK885LK885\&oq=What+is+a+national+park\%3F + Stage $+2+$ HSIE+-

+ Teacher's+Guide+(2015)+National+Parks+and+Wil dlife+Service\%2C+Office+of+Environment+and+Her itage $\% 2 \mathrm{C}+$ nationalparks.nsw.gov.au\&aqs $=$ chrome.. 6 9i57.1159j0j9\&sourceid $=$ chrome \&ie $=$ UTF -8

- National Parks UK. (2021). Teaching Resources. National Parks UK. https://www.nationalparks.uk/teaching-resources/

- National Recreation and Park Association. (2020). Parks and Recreation. Https://Www.Nrpa.Org/. https://www.nrpa.org/

- Nielsen, H., \& Bronwen Player, K. M. (2009). Urban Green Space Interventions and Health. http://www.euro.who.int/pubrequest
- Oxford Advanced Learner's Dictionary. (2020). pitch_1 noun - Definition, pictures, pronunciation and usage notes $\mid$. Oxford Advanced Learner's Dictionary at OxfordLearnersDictionaries.Com. https://www.oxfordlearnersdictionaries.com/definition /english/pitch_1?q=Pitch

- Oxford Dictionary. (2020). PARK | Definition of PARK. Oxford Dictionary on Lexico.Com. https://www.lexico.com/definition/park

- OxfordLearnersDictionaries. (2020). estate noun Definition, pictures, pronunciation and usage notes. Oxford Advanced Learner's Dictionary. https://www.oxfordlearnersdictionaries.com/definition /english/estate?q=estate

- Pemaratana, S. (2001). BRINGING THE BUDDHA CLOSER: THE ROLE OF VENERATING THE BUDDHA IN THE MODERNIZATION OF BUDDHISM IN SRI LANKA.

- Power Thesaurus. (2020). Park synonyms - 1389 Words and Phrases for Park. Power Thesaurus. https://www.powerthesaurus.org/park/synonyms

- Ruegg, D. S. (1999). A new publication on the date and historiography of the Buddha's decease (nirvāncombining dot belowa): A review article. Bulletin of the School of Oriental and African Studies, 62(1), https://doi.org/10.1017/s0041977x00017572

- School of Hotel and Tourism Management, T. H. K. P. U. and P. S. (2020). Theme Park. https://www.edb.gov.hk/attachment/en/curriculumdevelopment/kla/pshe/references-andresources/tourism/Theme_Park_en.pdf

- Scrabble Word Solver and Dictionary. (2020). Definition of park | What does park mean? Scrabble Word Solver and Dictionary. https://www.scrabblewordsolver.com/define-aword/park/

- Sivasundaram, S. (2007). Tales of the Land: British Geography and Kandyan Resistance in Sri Lanka, 1803-1850. Modern Asian Studies, 41(5), 925-965. http://eprints.lse.ac.uk/21723/1/Tales_of_the_landBritish_geography_and_Kandyan_resistance_in_Sri_ Lanka_c_1803-1850.pdf

- Spencer, R., \& Cross, R. (2016). The origins of botanic gardens and their relation to plant science, with special reference to horticultural botany and cultivated plant taxonomy https://www.researchgate.net/profile/Roger_Spencer/p ublication/320173850_The_origins_of_botanic_garde ns_and_their_relation_to_plant_science_with_special _reference_to_horticultural_botany_and_cultivated_pl ant_taxonomy/links/59d2e1070f7e9b4fd7fc9ae4/Theorigins-of-botanic-gardens-and-their-relation-to-plantscience-with-special-reference-to-horticulturalbotany-and-cultivated-plant-taxonomy.pdf

- Strathern, A. (2009). The Vijaya Origin Myth of Sri Lanka and the Strangeness of Kingship. Oxford Journals. https://doi.org/10.1093/pastj/gtp019

- Synonym.com. (2020). Synonyms and Antonyms for park. https://www.synonym.com/synonyms/park 
- Synonyms.com. (2020). Park Synonyms \& Antonyms. STANDS4 LLC. https://www.synonyms.com/synonym/park

- T.W. Rhys Davids, \& C.A.F. Rhys Davids. (1900, January). Tripitaka: Complete English Translation . https://www.amazon.com/Tripitaka-CompleteEnglish-Translation-Volumes/dp/B005BRFM7I

- The Free Dictionary. (2020). Park - definition of park. The Free Dictionary. https://www.thefreedictionary.com/park

- Thesaurus.com. (2013). PARK Synonyms \& Antonyms. Philip Lief Group. https://www.thesaurus.com/browse/park

- Türkseven Doğrusoy, I., \& Zengel, R. (2017). Analysis of perceived safety in urban parks: A field study in Büyükpark and Hasanaga Park. Metu Journal of the Faculty of Architecture, 34(1), 63-84. https://doi.org/10.4305/METU.JFA.2017.1.7

- United Nations Educational, S. and C. O. (2020). UNESCO Global Geoparks. UNESCO Global Geoparks - $\quad$ Earth Sciences. http://www.unesco.org/new/en/naturalsciences/environment/earth-sciences/unesco-globalgeoparks/

- Urban Dictionary. (2019). Urban Dictionary: Parks. Urban Dictionary. https://www.urbandictionary.com/define.php?term=P arks
- Vidová, J. (2010). Industrial parks - history, present and its influence to the employment. Review of Economic Perspectives, 10(1), 41-58. https://doi.org/10.2478/v10135-009-0008-1

- Vidyalankaara Campus. (2001). 巳ого

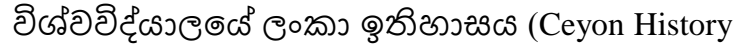
of Ceylon Campus) (2nd-Sinhal ed.). Vidyalankaara Campus.

- Wisdom Library. (2018, June 22). Ranmasu Uyana: 1 definition._Info@wisdomlib.Org. https://www.wisdomlib.org/definition/ranmasuuyana\#history

- Witzel, M. (2019). Early 'Aryans' and their neighbors outside and inside India. Journal of Biosciences, 44(3), 58. https://doi.org/10.1007/s12038-019-9881-7

- WordHippo Thesaurus. (2020). What is another word for park? | Park Synonyms . WordHippo Thesaurus. https://www.wordhippo.com/what-is/another-wordfor/park.html\#/

- World Health Organization. (2021). WHO Coronavirus (COVID-19) Dashboard. https://covid19.who.int/

- You're Dictionary. (2020a). Park Meaning | Best 46 Definitions of Park. Your Dictionary. https://www.yourdictionary.com/park

- Your Dictionary. (2020b). Park synonyms | Best 63 synonyms for park. Thesaurus.Yourdictionary.Com. https://thesaurus.yourdictionary.com/park 